\title{
Index autorum ad Vol. 9
}

$\mathrm{B}=$ Buchbesprechung - Book Review - Livre nouveau

Bakan, D., 84-88

Fiske, D.W., 74-83

Fowler, W., 18-29

Gooch, S., 177-208

Henry, W.E., 47-56

Kellmer Pringle, M.L., 121-151,

177-208 Kohlberg, L., 5-17 Kragh, U., 209-221 Kroon,T, 209-221

Lehr, U., 174-175 (B) LeVine, R.A., 30-46

LIEBERMANN, M.A., 57-60

Lyeshout, C.F.M. van, 152-173 Munnichs, J. M. A., 230-245 Neugarten, Bernice L., 61-73

Orme,J.E., 222-229 Riegel, K.F., 97-120 Thomae, H., 174 (B) Wall, W.D., 121-151 